\title{
The Russell Colloquium at McMaster
}

Four more workshops were held before the end of term. Nicholas Griffin spoke on 'Wittgenstein and Russell's Multiple Relation Theory of Judgment" (March 7, 197?); Louis Greenspan gave the third part of his essay, "Russell: Science and Liberty" (March 14); Ron Goldstein digested his M.A. thesis on Political Science for us under the title "Russell's Socialism" (March 28); and Carl Spadoni gave us the results of his researches on "Russell's Rebellion against Neo-Hegelianism" (April 11). The main event, however, was the first Russelt Lecture, on the topic of "Russell's First Crusade: Free Trade and the New Liberalism, 1903-1914". It was delivered on March 17, 1977, by R.A. Rempel. We print below the opening remarks of the Lecture's chairman, Professor A. Berland, Deom of Humanities, MoMaster. Dr. Rempel's papex will likely appear in the Journal of the History of Ideas.

The Bertrand Russell Archives, housed at McMaster University, may well 1 be the most important single archival collection in Canada. A first major acquisition took place in 1968, the second in 1972. How the Archives came to us, in Canada, in Hamilton, in McMaster, is a story that merits retelling--preferably by a bard, accompanying himself with lute. I shall not attempt that heroic account this evening. EXCEPT to say that the Russell Archives, which are continually being added to, now contain some quarter-million items, including large numbers of unpubl ished essays, reviews, scholarly and popular papers, and an extraordinarily rich correspondence.

When McMaster acquired the Archives we believed that they would be an invaluable primary source for research in fields as diverse as mathematics, logic, social philosophy, political philosophy, the history of science, education, religion, moral philosophy, and literature. That this expectation was well founded has been demonstrated by the rich use made of the Archives by scholars both within McMaster, and throughout the academic world of North America, England, Europe, and Asia.

Another aspect of the Archives' interests has been the publication over the years of Russelz: the Journal of the Bertrand Russelz Archives. Still another has been our work over recent years toward the hoped-for publication of an accurate and complete Collected Essays of Bertrand Russell. One measure of the magnitude of that task lies in the fact that Russell wrote some 2,500 essays alone. Almost all of these are now--in one form or another--in the Archives.

Still another benefit of the Archives has been the creation, just this last year, of a Bertrand Russel1 Archives Advisory Board, which I have the honour of chairing, and with a membership drawn from McMaster, York, and Toronto. The Advisory Board has been concerned with a number of issues, foremost among them ways of improving the interface between the Archives and the University's research and teaching programmes. 
Continued from page 3

Out of the Advisory Board came the splendid proposal for providing a forum for new work in Russell studies. Two levels of activity were proposed. First, a series of workshops to be led by local faculty, visiting researchers, neighbouring scholars, and graduate students, in which new and ongoing Russell research mightbe shared, discussed, and debated. The workshops have been 1aunched, just this last month, by Dr. Louis Greenspan of the McMaster Department of Religious Studies, on the subject of Russell's ideas on Science and Liberty.

The second level of activity proposed for the Russell Colloquium is a number of formal lectures, to be given once or at most twice a year. And it is the first of these lectures which we are privileged to be present for this evening.

Our speaker, Professor Richard Rempel, was educated at the University of Saskatchewan and at Oxford where he was a Rhodes Scholar, and where he earned his M.A. and Ph.D. Dr. Rempel then spent some 11 years at the University of South Carolina, where he won an impressive series of awards, for distinguished teaching, for student counselling, and for contributions to university life. He joined the Department of History at McMaster in 1975. He has published in book form and in articles in the field of modern English history, particularly in areas related to free trade and tariffs, the Unionists, and the Boer War. Dr. Rempel's topic for this first Bertrand Russell Lecture is "Russe11's First Crusade: Free Trade and the New Liberalism, 1903-1914". 